\title{
Unusual rectal foreign body for drug screen evasion
}

\author{
John Chi To Wong, ${ }^{1}$ Alan Hoi Lun Yau, ${ }^{2}$ Hin Hin $\mathrm{Ko}^{2}$
}

'Department of Medicine, University of British Columbia, Vancouver, British Columbia, Canada

${ }^{2}$ St. Paul's Hospital, University of British Columbia, Vancouver, British Columbia, Canada

\section{Correspondence to Dr Alan Hoi Lun Yau, yauhoilun@gmail.com}

Accepted 6 December 2014

\section{DESCRIPTION}

A patient with chronic pain on methadone presented with difficulty passing stools and left lower abdominal discomfort for 7 days. His medical history was unremarkable. Abdominal examination demonstrated mild tenderness in the left lower quadrant. A routine rectal examination revealed a mobile object with a blunted end without blood on the examining glove. Blood work showed a normal complete blood count. Abdominal radiograph identified a rectal object. Endoscopy showed a pinkcoloured rounded object with a smooth surface at $10 \mathrm{~cm}$ from the anal verge nearly obstructing the lumen without mucosal lacerations or other complications (figure 1A). A loop snare was used to remove the rectal object which measured $8 \times 3 \mathrm{~cm}$ and was tapered at one end (figure $1 \mathrm{~B}$ ). The pink wrapping was cut open, revealing a plastic bottle, which was emptied yielding a clear yellow liquid (figure 1C). On further questioning, the patient revealed that he had filled an eye drop container with a friend's 'clean' urine, wrapped it inside a condom, and voluntarily inserted it into his rectum to maintain the urine at body temperature for later retrieval at a methadone dispensing centre in order to evade regular screening of recreational drug use.

Our patient's rectal foreign body presentation is characteristic: young male; delay in disease presentation after failed self-removal; and reluctance for full disclosure. ${ }^{1}$ Physicians require a high index of suspicion when evaluating patients for bowel obstruction, rectal bleeding, peritonitis and drug toxicity; order radiographic imaging to localise and size the object; and consider endoscopic visualisation. ${ }^{1}$ Extraction techniques include trans anal manual removal; endoscopic extraction with snares, forceps, catheters and balloons; and laporatomy with repair of complications. ${ }^{2}{ }^{3}$ Using the rectum to maintain 'clean' urine at body temperature for drug screen evasion has not been previously described, adding to drug smuggling, sexual gratification and involuntary acts as causes of rectal foreign bodies. ${ }^{1}$

\section{Learning points}

- Drug screen evasion is an uncommon cause of rectal foreign bodies.

- Rectal foreign bodies may be identified radiologically and/or endoscopically.

- Rectal foreign bodies may be removed manually, endoscopically or surgically.

Contributors JCTW was involved with review of the literature and drafting of the manuscript. AHLY was involved with the drafting and submission of the manuscript. HHK was involved with the description of endoscopic images and final approval of the manuscript.

Competing interests None.

Patient consent Not obtained.

Provenance and peer review Not commissioned; externally pee reviewed.

\section{REFERENCES}

1 Goldberg JE, Steele SR. Rectal foreign bodies. Surg Clin North Am 2010;90:173-84.

2 Koornstra JJ, Weersma RK. Management of rectal foreign bodies: description of a new technique and clinical practice guidelines. World J Gastroenterol 2008;14:4403-6.

3 Cologne KG, Ault GT. Rectal foreign bodies: what is the current standard? Clin Colon Rectal Surg 2012;25:214-18.
To cite: Wong $\mathrm{JCT}$, Yau AHL, Ko HH. BMJ Case Rep Published online: [please include Day Month Yearl doi:10.1136/bcr-2014207897
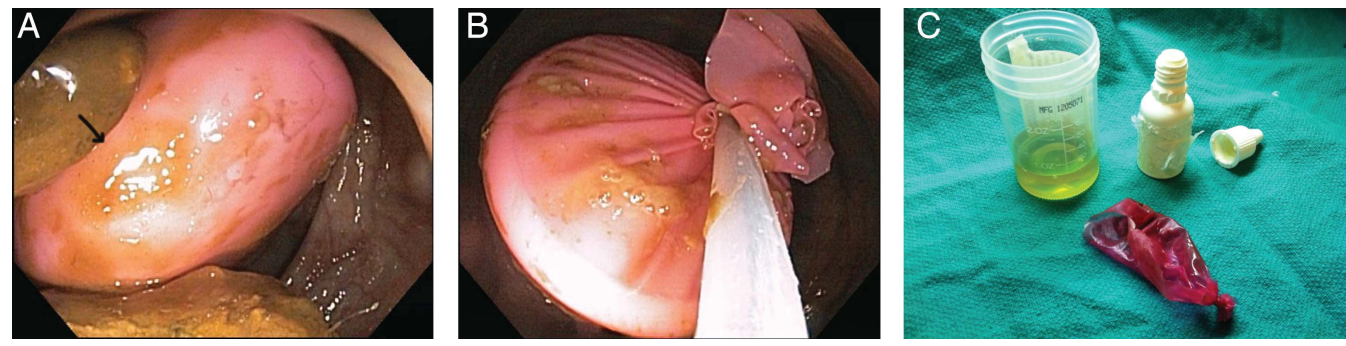

Figure 1 Rectal foreign body (A) on endoscopy at $5 \mathrm{~cm}$ from the anal verge, (B) being removed with a loop snare, and $(C)$ yielding a yellow-coloured liquid on emptying. 
Copyright 2014 BMJ Publishing Group. All rights reserved. For permission to reuse any of this content visit http://group.bmj.com/group/rights-licensing/permissions.

BMJ Case Report Fellows may re-use this article for personal use and teaching without any further permission.

Become a Fellow of BMJ Case Reports today and you can:

- Submit as many cases as you like

- Enjoy fast sympathetic peer review and rapid publication of accepted articles

- Access all the published articles

- Re-use any of the published material for personal use and teaching without further permission

For information on Institutional Fellowships contact consortiasales@bmjgroup.com

Visit casereports.bmj.com for more articles like this and to become a Fellow 